\title{
Analysis of the potential of landfill gas as an alternative for electrical energy source
}

\author{
Edi Munawar ${ }^{1}{ }^{*}$, Nikita Emalya ${ }^{1}$, Adinda Puspa Hayati ${ }^{1}$, Yunardi $^{1}$ and Lukman Hakim ${ }^{2}$ \\ ${ }^{1}$ Department of Chemical Engineering, Faculty of Engineering, Syiah Kuala University, Jl. Tgk. Syech Abdur Rauf 7 \\ Darussalam, Banda Aceh 23111, Indonesia \\ ${ }^{2}$ Department of Chemical Engineering, Faculty of Engineering, Malikussaleh University, Jl. Cot Tengku Nie Reuleut, \\ Muara Batu, North Aceh, Indonesia
}

\begin{abstract}
Municipal solid waste (MSW) is generated from human activities, where most of them end up at the landfill. The landfill gas produced from the degradation of organic matter in the MSW landfill contains methane can be used as the energy source. Therefore, the objective of this research is to analyze the potential of landfill gas as an alternative for energy source. Two Landfill Simulator Reactor (LSRs) made of high density polyethylene (HDPE) pipe has $50 \mathrm{~cm}$ outside diameter and $150 \mathrm{~cm}$ of height were operated under natural condition. The first LSR was operated without leachate recirculation (A), while the other one was operated with leachate recirculation (B). Results of this research found the highest methane concentration from LSR A was about $53 \%$ and $41.8 \%$ from LSR B. This finding was applied to estimate the landfill gas production for electricity generation in Cot Padang Nila landfill. The potential electrical energy that could be produced from Cot Padang Nila landfill is $203 \mathrm{MWh} /$ year if it is operated using LSR A mode, and $161 \mathrm{MWh} /$ year when operated in accordance to LSR B mode. This amounts of energy is suitable to provide electricity for 53-67 households in the vicinity of the landfill.
\end{abstract}

\section{Introduction}

The Government of Indonesian enacted the Act 18 on Waste Management in May 2008. This acts is requires the MSW management authorities to implement the integrated waste management according to the waste hierarchy, namely reduce, reuse and recycle (3Rs) [1, 2]. The MSW management includes waste collection, sorting and disposal at landfill site. The landfilling of MSW should be carried out in an environmentally sound manner in order to avoid the waste management impacts on humans and the environment. In addition, the Act also obliges the local governments to close the MSW landfills that operate as an open dump no later than five years after enactment of this Act. Within the same time frame, the new landfills should be construct to replace the open dump ones. The construction, operation and closure of the open dump should be carried out in accordance with the standards and regulations in force [2].

Although there are no exact number the MSW landfillsin operation, the State Ministry of Environment (MoE) estimated that all districts and municipalities have at least one landfill inoperation. In 2006, the amount of MSW generated and collected was estimated to be around 38.5 million tons [3]. Most of it was ended up at landfill sites across the 126 districts and municipalities, while only $7 \%$ of the waste generated and collected was recycled or composted. Furthermore, about $37 \%$ of the total MSW was generated from major cities such as Jakarta, Bandung, Surabaya, Medan, etc. [3].

The landfilling of MSW is associates with the environment problems, such as aesthetic problems, air pollution and groundwater contamination. Soil contamination is caused by leachate, a liquid which is produce of degradation organic matter of MSW, including the precipitation that has percolated through the landfilled MSW. The leached contain any soluble materials such as salt, organic and nitrogen compounds. In addition to the leachate, the degradation organic matter of MSW also produces gas with the major component are methane (CH4) and carbon dioxide (CO2). These two gases are classified as greenhouse gas (GHGs) that caused the increase of atmospheric temperature so called global warming effect. According to Pohland [4], the quantity and composition of landfill gas formed was significantly influenced by the age of landfilled waste. At the same time, the landfills gas is represent the energy resource that lost and polluted the ambient air since most landfill does not equipped landfill gas capture facilities which is subsequently use as energy source.

Many scientific investigations regarding landfilling emission have been conducted, including the landfill impacts on water resource, land use, health and biodiversity. However, most of them was conducted in temperate climate regions, where the temperature throughout the year varies widely and the precipitation

* Corresponding author: edi.munawar@ unsyiah.ac.id 
rate was very low compare to the tropical climate regions. Therefore, the objective of this study is to evaluate the landfill gas production of closed landfill, particularly in tropical climate region which is identified with high precipitation rate by using landfill simulator and evaluate its potential as energy source.

\section{Materials and methods}

\subsection{Sample preparation}

MSW used in this research was collected from Cot Padang Nila Landfill in Pidie district. The landfill site is located at Tunong Tanjung village, Padang Tiji, Pidie district $\left(5^{\circ} 26^{\prime} 24.3^{\prime \prime} \mathrm{N} 95^{\circ} 49^{\prime} 10.9^{\prime \prime} \mathrm{E}\right)$, which is about 86 $\mathrm{km}$ southeast of Banda Aceh city. The Cot Padang Nila landfill was constructed to receive MSW generated from Pidie district area and it has been operated for about 10 years. This landfill has a total area of around 2.2 ha equipped with 3 landfilling cells, leachate treatment pond, and other supporting facilities. The landfill was built with the support of the United Nations Development Programme (UNDP) after the tsunami disaster 2004 and was operated immediately after the completion.

All samples for this research were taken from aged solid waste in the landfill. The aged waste in the landfill existed in the first cell which has been closed since 2012. An amount of more than three tons of waste was excavated from a depth of 3 meters where the first cell located in the landfill. Most of the waste consisted of inorganic matters such as plastic sheet, rubbers, textiles, and woods mixed with soil. The waste was then screened to get one ton sample having a particle sizes of around 1 to $5 \mathrm{~cm}$. Sample was later transported to the laboratory in Darussalam Banda Aceh for further experiment in the reactors.

\subsection{Landfill simulator reactor (LSR) set-up}

Two LSRs made of high density polyethylene (HDPE) pipe a $50 \mathrm{~cm}$ outside diameter, $2.5 \mathrm{~cm}$ wall thickness and $1,500 \mathrm{~cm}$ in height have been used in this research. Each reactor has a total volume of approximately $0.57 \mathrm{~m} 3$. The top and bottom lids of the reactor were also made of HDPE. A port for biogas collection was installed on the top lid while another port was equipped at the bottom lid for the purpose of leachate collection. In addition to biogas collection port, a showerhead has also been installed on the top lid for leachate recirculation or fresh water addition to simulate the rainfall.

The biogas outlet port is connected to the eudiometer which measures the volume of generated biogas. A rubber tube is used to connect between the eudiometer and gas analyzer (Multitec 540 SEWERIN) for the purpose of determination of biogas composition. The leachate outlet port is connected to U-type silicon tube to prevent the ambient air entering to the LSR after draining out the leachate. An external plastic container of 10 liter capacity was placed to collect the leachate produced from each LSR and re-circulate it into the LSR, depending on type of reactor operation. Four thermocouples were installed in each LSR to measure the internal temperature. A distance of $20 \mathrm{~cm}$ was used to position between one thermocouple to another. In an effort to minimize the heat loss from inside the reactor to the ambient air, each reactor was covered by two layers of blanket made of synthetic wool and aluminum foil. There has been no electrical device was used to maintain the internal temperature.

Each LSR was filled with a $15 \mathrm{~cm}$ layer of gravels having a particle size ranging from $1-2.5 \mathrm{~cm}$ at the bottom of the reactor. The gravel bed was covered by using geo-textile sheet to prevent the pore of the bed from clogging by waste materials. At the top of the LSR, an empty space of $15 \mathrm{~cm}$ from the top was as headspace. The detailed configuration of the LSR is illustrated in Figure 1.

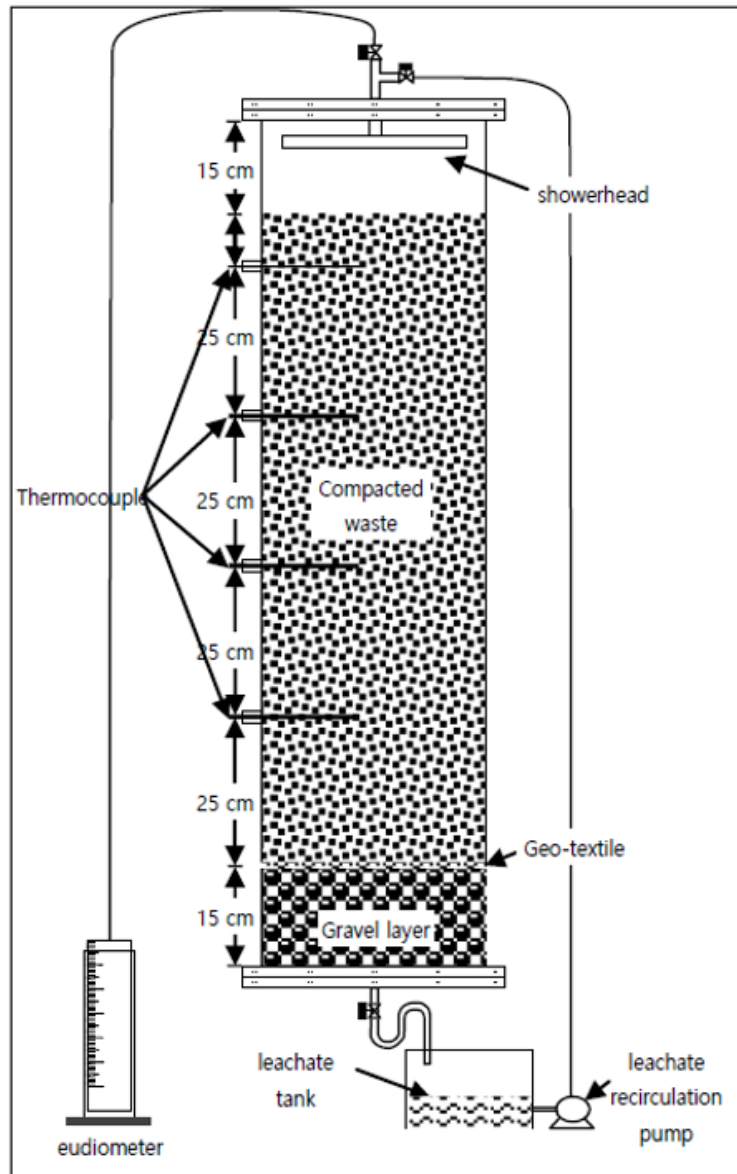

Figure 1. Experimental setup of landfill simulator reactor.

Initially, each reactor was fed with a $5 \mathrm{~L}$ leachate taken from the leachate pond at Cot Padang Nila landfill site. The first leachate from each reactor was collected after seven days of operation. The Two LSRs were operated into two modes in this experiment. The first reactor was categorized as LSR A, and the remaining as LSR B. The LSR A was operated without leachate circulation, instead fresh water was added on regular basis. On the contrary, the LSR B was run through recycling the leachate to the top of the reactor on a daily 

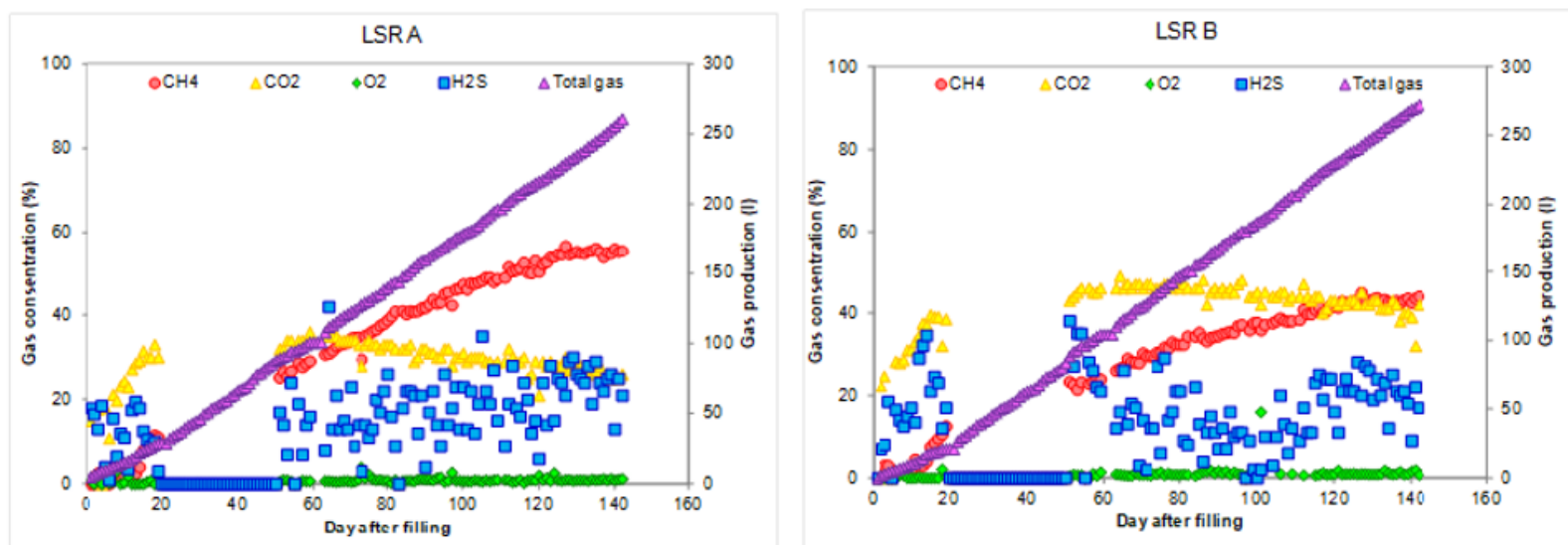

Figure 2. Landfill gas composition produced from LSR A operates without leachate circulation (left) and LSR B with leachate circulation (right).

basis. Based on the calculation of rainfall in a tropical climate region, then the volume of rainfall obtained everyday is $1.8 \mathrm{~L}$. Therefore the fresh water and leachate added to each LSR is $1.8 \mathrm{~L}$, depending on the type of the LSR. In case the volume of the recirculation leachate did not reach $1.8 \mathrm{~L}$, then some tap water was added to meet a volume of $1.8 \mathrm{~L}$.

\subsection{Analytic procedures}

During the experiment, the volume of produced gas was measured using eudiometer and the gas composition $\left(\mathrm{CH}_{4}, \mathrm{CO}_{2}, \mathrm{O}_{2}\right.$ and $\left.\mathrm{H}_{2} \mathrm{~S}\right)$ was measured using gas analyzer (Multitec 540 SEWERIN). Leachate samples were analyzed for $\mathrm{pH}$ using $\mathrm{pH}$ meter (HANNA instruments, HI 9126), electrical conductivity (EC) using conductivity meter (CORNING Pinnacle, Model 541), BOD5 using BOD sensor and incubator (VELP Scientifica BOD system). The $\mathrm{COD}$ and $\mathrm{NH}_{4}$ were analyzed using spectrometer (Shimadzu UV-VIS 1800) and heavy metal content in the leachate, particularly iron (Fe), was analyzed using Atomic Absorption Spectrophotometer (Shimadzu AA-6300). The elemental compositions of biogas, including $\mathrm{CH}_{4}, \mathrm{CO}_{2}, \mathrm{O}_{2}$ and $\mathrm{H}_{2} \mathrm{~S}$ together with volume of gas and leachate were measured daily. In addition, internal LSR temperature as well as leachate temperature, leachate $\mathrm{pH}$ and $\mathrm{EC}$ were also measured on daily basis. Measurements of BOD5, COD, $\mathrm{NH}_{4}$ and $\mathrm{Fe}$ were analyzed once a week.

\section{Results and discussion}

\subsection{Landfill gas production}

Figure 2 illustrates the composition of landfill gas production from LSR A and LSR B. The rate of landfill gas production approximately was around $1.8 \mathrm{~L} /$ day. This amount was one tenth lower compare to the reactor operate by using fresh MSW. It could be understood since the organic content in the aged solid waste is much lower than the fresh solid wastes. The organic matters in the aged solid waste almost degraded over the ten years in MSW landfill.
It can be observed from Figure 2 that the landfill gas production was started slowly during the first few days of operation and its composition mainly $\mathrm{CO}_{2}[5,6]$. Low concentration of $\mathrm{CH}_{4}$ in the landfill gas is occurs in early stage of anaerobic degradation process, where the acidogenic processes is taken place. This is condition also happened for LSR operated using fresh solid waste. The gas production then increases by time in line with rapid growth of the microorganism in the reactor. During the first few days of operation, the concentration of methane gas from LSR A was $2.5 \%$ while from LSR B was $3 \%$. The gas production gradually increased until 100 th day of which the concentration of $\mathrm{CH}_{4}$ was reaching up to $40 \%-50 \%$. The highest concentration of $\mathrm{CH}_{4}$ approximately $53 \%$ and $41.8 \%$ was observed in the LSR A and the LSR B, respectively. This results indicate that higher $\mathrm{CH}_{4}$ concentration was obtained from the LSR was operated under without leachate recirculation. This finding is not in agreement with previous research reported by Septiropa (2012) [7]. She claiming that the leachate circulation can maintain the moisture of waste and increase $\mathrm{CH}_{4}$ concentrations. In the LSR A, such higher concentration of $\mathrm{CH}_{4}$ could be achieved probably due to the moisture content of solid waste inside is kept by pouring fresh water. In addition, the low $\mathrm{CH}_{4}$ formation in LSR $B$ can be caused by slow methanogenic growth inhibited by high nitrogen and heavy metals concentration in recycled leachate. It should be noted that, the ammonium and heavy metals content in the leachate can be toxic for microorganism [8].

\subsection{Physical-chemical parameters}

In addition to composition and volume of landfill gas, the physical-chemical parameters of leachate were also measured. Physical-chemical parameters measurements include temperature, $\mathrm{pH}$ and electrical conductivity (EC). The temperature was measured using four channels digital thermometer equipped with thermocouple. The 4 thermocouples were installed at a distance of $20 \mathrm{~cm}$ from the bottom of the LSR. The data 

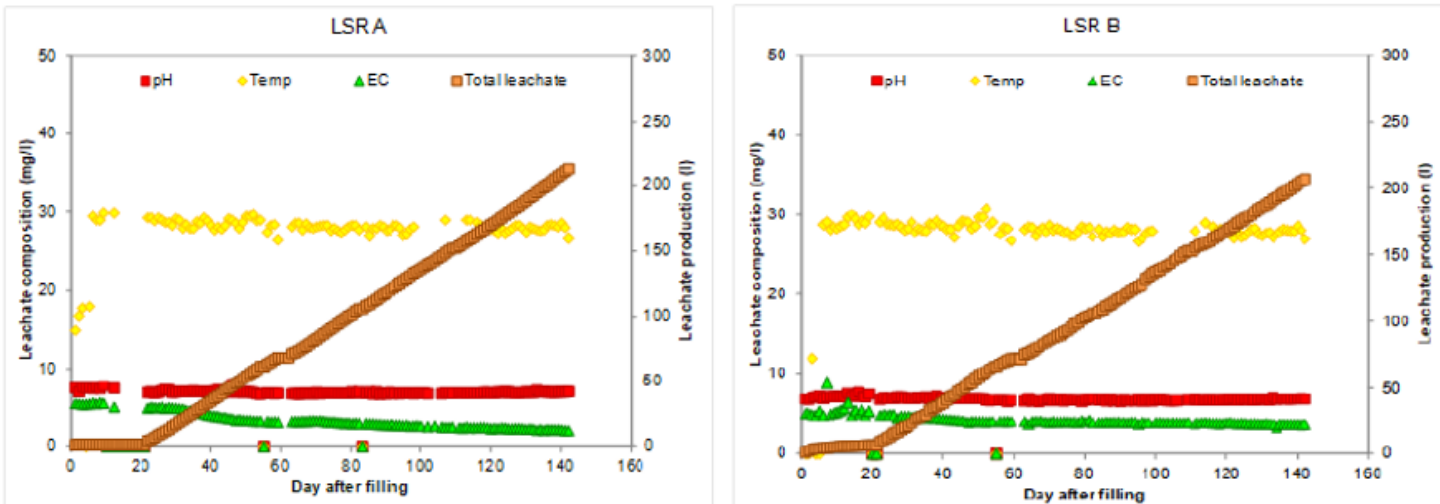

Figure 3. Physical-chemical parameters from LSR A operates without leachate circulation (left) and LSR B with leachate circulation (right).

were taken daily. Figure 3 shows physical-chemical parameters from each LSR.

The temperature is an important indicator in determining the progress of chemical and physical reactions of a particular system [9]. It also greatly affects the solubility of oxygen, turbidity and the organism activity. Each microorganism has specific temperature for optimum growth since its quite sensitive to environmental temperature [10]. Intern of inside LSR environment, it is clear that the anaerobic condition occurred inside the reactor. This evidenced is indicated by the depleting of oxygen as shown in Figure 3. The installed blanked can block the heat loss from inside LSR to the surrounding area and kept the LSR temperature close to optimum temperature for microorganism growth. It is indicated by temperature different between inside the LSRs and surrounding area. The average room temperature where the reactors were place was around $26^{\circ} \mathrm{C}$, while inside the LSR A and LSR $\mathrm{B}$ the temperature were $28.3^{\circ} \mathrm{C}\left( \pm 0.9^{\circ} \mathrm{C}\right)$ and $28.3^{\circ} \mathrm{C}$ $\left( \pm 1^{\circ} \mathrm{C}\right)$, respectively. Figure 3 shows the temperature change inside the LSR during 100 days of LSR operation.

In addition to the temperature, $\mathrm{pH}$ can also be used as an indicator for anaerobic microbial activity. $\mathrm{pH}$ is influenced by production the hydrogen ions in the solution. The $\mathrm{pH}$ of the leachate indicates the concentration the hydrogen ions in leachate and depending on the process is taking place. There was no significant change in $\mathrm{pH}$ value of the leachate. The $\mathrm{pH}$ value was relatively constant during the LSR operation. The $\mathrm{pH}$ value of LSR A and LSR B were $6.9( \pm 0.24)$ and $6.9( \pm 0.23)$, respectively. With regard to the EC, the EC of leachate from LSR A was gradually decrease until the end of observation. Compared to the LSR B which was tends to steadily until the end of observation. This might be due to a regular pour of water that makes the salt in the solid waste was dissolved into the leachate. Results from this study are in agreement with those obtained by Valencia et al (2009) [5, 6].

\subsection{Biological parameters}

Biological and chemical analysis on the leachate was conducted once a week to determined the organic substances and heavy metals content. Biological and chemical parameters which are regularly measured include $\mathrm{NH}_{4}$, heavy metal (Fe), Chemical Oxygen Demand (COD) and Biological Oxygen Demand (BOD). Among these parameters, COD and BOD are the main parameters in determination of organic degradation process. The relationship between time of operation and biological and chemical parameters of leachate produced from LSR A and LSR B is demonstrated in Figure 4.

In this study, the COD concentration for LSR A was ranged between $236-1,715 \mathrm{mg} / \mathrm{L}$ and the COD concentration for LSR B was ranged between 321-1,822 $\mathrm{mg} / \mathrm{L}$. This results also indicated, most landfill operator need treat leachate produced from their landfill until meeting the regulated quality before its discharged into the environment. It is very important since from the previous study found most landfill was not treat their leachate properly [14].

In this study, values of BOD5 in LSR A ranged between $92-120 \mathrm{mg} / \mathrm{L}$ and $\mathrm{BOD}_{5}$ of $\mathrm{LSR}$ B ranged between $59-221 \mathrm{mg} / \mathrm{L}$. The results of this study are in accordance with those expressed by Usman and Santosa (2014) [13]. In their study, the leachate from landfill was treated using the constructed wetland which showed that the BOD value reached of $100-200 \mathrm{mg} / \mathrm{L}$. However, it should be noted that the results obtained from the LSRs may not represent the real the landfill, since the organic matter contained in the landfill is more varied and plentiful.

The heavy metal content in the leachate of unlined landfill posed threat the human being health through the underground water pollution in the surrounding areas. The highest Fe contents in leachate of LSR A and LSR B were 4.7037 and $4.8722 \mathrm{mg} / \mathrm{L}$, respectively. These results are comparable with a similar study conducted by Irhamni et al. (2017) [18], which found that the iron content in the leachate in tropical climate was 10.9191 $\mathrm{mg} / \mathrm{L}$. Based on the Regulation Minister of Environment Republic of Indonesia No. 5/2014 on the quality standard of wastewater that can be discharged to water body, the $\mathrm{Fe}$ concentration in wastewater before discharge to water body shall as low as $5 \mathrm{mg} / \mathrm{L}$. Correlating the regulation with the results of the present study suggest that the $\mathrm{Fe}$ in the leachate from both LSRs are still below the threshold value and it can be discharged directly to the water body. 
A $\mathrm{NH}_{4}$ measurement was performed to determined the $\mathrm{NH}_{4}$ concentration and compared to the threshold level according to the Government regulation. From the observation results, shown the $\mathrm{NH}_{4}$ concentration of LSR A was do not change significantly during the LSR operation and tend to be stable about 12-14 mg/l. Meanwhile, $\mathrm{NH}_{4}$ concentration in LSR B was gradually increase from 11 to $28 \mathrm{mg} / \mathrm{L}$. This results is in accordance with study reported by Torobi et al. (2015) [20]. In their study that focused on the $\mathrm{NH}_{4}$ reduction in landfill leachate of an anaerobic aerobic system and aerobic culture algae, the $\mathrm{NH}_{4}$ concentration also tends to increase until $>500 \mathrm{mg} / \mathrm{L}$. Compare to the regulation in force, results of the study indicates that $\mathrm{NH}_{4}$ concentration in leachate is still higher than the threshold then it is necessary to treat the leachate before discharged into the water body.

The biodegradability of a liquid waste can be illustrated with a BOD/COD ratio. The BOD/COD ratio represents the proportion of biodegradable organics in the leachate. This ratio is normally higher in young landfills (fresh solid waste) than its become low in older landfills (old solid waste) [15]. The BOD/COD ratio also can be an indicator to predict the effectiveness of degradation organic matter in the solid waste, and wastewater. When the rate degradation of organic matter is getting higher, then the BOD/COD ratio will be also greater [21]. Figure 5 shows the evolution of BOD/COD ratio from each reactor during 100 days of observation.

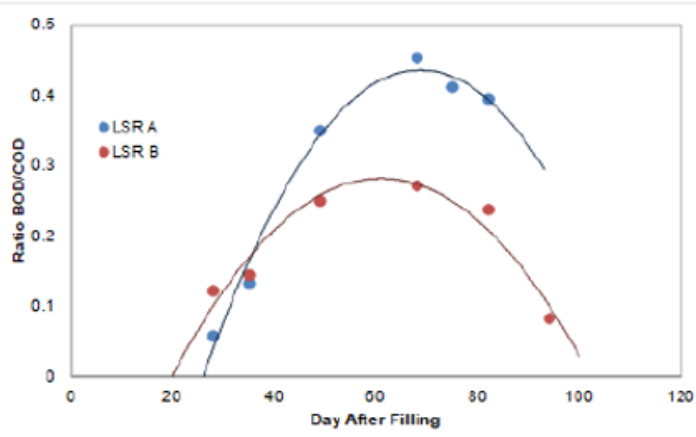

Figure 5. BOD/COD Ratio in the leachate from each reactor.

\subsection{The potential electricity production from landfill}

The landfill gas production from MSW landfill was calculated based on the gas production rate per certain mass of solid waste from the LSR. The production rate of gas from landfill was calculated by using the following equation:

$$
V_{L}=\frac{\left(v_{L S R} \times f_{M}\right) \times m_{L}}{m_{R}}
$$

where, is the gas production from the landfill ( $\left.\mathrm{m}_{3} / \mathrm{day}\right)$, is the gas production from the landfill LSR (m3/day), $f_{M}$ is fraction of $\mathrm{CH}_{4}$ in gas produced from LSR (\%), is mass of waste in the landfill and is mass of solid waste in the landfill. The potential electricity production from landfill was calculated by using the following equation:

$$
E=V_{L} \times H V \times \eta_{\text {electrical }} \times \frac{360}{1000}
$$

where, $\mathrm{E}$ is the electrical energy potential (MWh/year), $\mathrm{HV}$ is heating value $\left(\mathrm{kWh} / \mathrm{m}_{3}\right)$ and $\eta_{\text {e electrical is an }}$ electrical efficiency.

The potential electrical energy was calculated by assuming the heating value of methane gas equals to 3.5$5.5 \mathrm{kWh} / \mathrm{m}_{3}$ for the $\mathrm{CH}_{4}$ concentration between $35-55 \%$ [25] and electrical power efficiency of $35 \%$ [26]. For this purpose, the methane gas concentrations from LSR A and LSR B are taken as $53 \%$ and $42 \%$, respectively. The calculation results shows that the Cot Padang Nila Landfill would be able to produce an energy of 203 MWh/year if its operated under the LSR A mode and $161 \mathrm{MWh} /$ year if its operated under LSR B mode. These amount of electrical is enough to provide an electricity approximately 53 to 67 households with 900 VA per house.

\section{Conclusion}

On the basis of results and discussion, the following conclusions can be drawn:

1. Of the two reactors, LSR A and LSR B, operated to simulate the landfill solid waste biodegradation, the reactor operated without leachate recirculation, produced higher $\mathrm{CH}_{4}$ concentration compared to that of the reactor with leachate recirculation.

2. The electrical energy potential from Cot Padang Nila landfill gives a $203 \mathrm{MWh} /$ year if its operated under the LSR A mode and a 151 $\mathrm{MWh} /$ year if its operated under the LSR B mode. Such electrical energy potential could provide electricity for a year to a number of 5367 households with 900 VA per house.

3. The temperature inside the LSR A and LSR B were $28.3^{\circ} \mathrm{C}\left( \pm 0.9^{\circ} \mathrm{C}\right)$ and $28.3^{\circ} \mathrm{C}\left( \pm 1^{\circ} \mathrm{C}\right)$, respectively and $\mathrm{pH}$ values for LSR A and LSR B were $6.9( \pm 0.24)$ and $6.9( \pm 0.23)$, respectively. While the electrical conductivity (EC) values decreased because of the decrease in dissolved salts.

4. The higher values of organic substances (BOD and COD), heavy metal (Fe) and ammonium $\left(\mathrm{NH}_{4}\right)$ in the leachate were found in the reactor which was operated under leachate recirculation.

The authors wish to express their gratitude to Syiah Kuala University, Banda Aceh, Indonesia for its financial support for the work described through International Cooperation Research Scheme, Contract No: 54/UN 11.2/PP/SP3/2017. 


\section{References}

[1] GoI, "Act 18 of 2008 of the Republic of Indonesia Number regarding Waste Management. Governance of Republic Indonesia, Jakarta, Indonesia.," ed, 2008.

[2] GoI, "The Goverment Regulation No. 81 of 2012 on Municipal Solid Waste Management, Jakarta, Indonesia," ed, 2012.

[3] MoE, "Indonesian Domestic Solid Waste Statistic Year 2008. 2008, State Ministry of Environment the Republic of Indonesia, Jakarta, Indonesia," ed, 2008.

[4] F. G. Pohland, "Leachate Recycle as Landfill Management Option," Journal of the Environmental Engineering Division, vol. 106, pp. 1057-1069, 1980.

[5] R. Valencia, W. van der Zon, H. Woelders, H. J. Lubberding, and H. J. Gijzen, "Achieving "Final Storage Quality" of municipal solid waste in pilot scale bioreactor landfills," Waste Management, vol. 29, pp. 78-85, 2009/01/01/ 2009.

[6] R. Valencia, W. van der Zon, H. Woelders, H. J. Lubberding, and H. J. Gijzen, "The effect of hydraulic conditions on waste stabilisation in bioreactor landfill simulators," Bioresource Technology, vol. 100, pp. 1754-1761, 2009.

[7] Z. Septiropa, "Design Interconnectionof Urban Solid Waste Bioreactor with Anaerobic Leachate Circulation Model to Increase Methane Gas Production," Journal of Gajah Mada University, vol. 8, pp. 171-176, 2012.

[8] I. Priyambada, B., M. A. Budiharjo, and J. Aprianti, "Effect of Leachate Recirculation on the Potential of Methane Gas Production (in Bahasa) " Presipitasi, Diponegoro University, vol. 7, pp. 36-41, 2010.

[9] C. N. Sawyer, L. Perry, McCart., and F. P. Gene, Chemistry for Environmental Engineering and Science. New York: McGraw Hill, 2003.

[10] F. Anindita, G. S. B. A. Kristanto, and D. M. Hartono, "Analysis of the Effect of Leachate Recirculation on the Total Suspended Solid (TSS) and Total Dissolved Solid (TDS) Concentrations in Leachate with Lysimeter (in Bahasa)," Faculty of Engineering, Indonesian University2013.

[11] D. R. Wardhani, R. D. Noriyanti, and T. Soehartanto, "Implementasi Estimator Kecepatan Pertumbuhan Mikroorganisme pada Bioreaktor Anaerob," Teknik Pomits, vol. 2, 2013.

[12] A. Rezagama, M. Hadiwidodo, P. Purwono, N. F. Ramadhani, and M. Yustika, "Elimination of Lindi Jatibarang Landfill Using Chemical Coagulation (in Bahasa)," Faculty of Engineering Journal, Diponegoro University, vol. 37, 2016.

[13] S. Usman and I. Santosa, "Treatmen Wastewater from Landfill using Constructed Wetland Method (in Bahasa)," Journal Health of Health Politeknik of Ministery of Health, Tanjung Karang, vol. 5, pp. 98-108, 2014.

[14] E. Munawar, Y. Yunardi, J. Lederer, and J. Fellner, "The development of landfill operation and management in Indonesia," Journal of Material Cycles and Waste Management, vol. 20, pp. 1128-1142, April 012018.

[15] S. Altouqi, "Modeling Leachate BOD and COD Using Lab-Scale Reactor Landfills and Multiple Linear Regression Analysis" Doctoral Thesis, The University of Texas Arlington, 2012.

[16] E. Damanhuri, I. Wahyu, R. Ramang, and T. Padmi, "Evaluation of municipal solid waste flow in the Bandung metropolitan area, Indonesia," Journal of Material Cycles and Waste Management, vol. 11, pp. 270-276, 2009.

[17] I. A. Sidauruk, G. S. B. A. Kristanto, and I. Gusniani, "Analysis of the Effect of Leachate Water Recirculation on Landfill Age in terms of Physical Parameters (Decrease in Waste, $\mathrm{pH}$ and Temperature) and Chemical Parameters (Biochemical Oxygen Demand and Chemical Oxygen Demand) on Landfill Bioreactors," Journal of Faculty Engineering Journal, Indonesian University, 2013.

[18] Irhamni., S. Pandia, E. Purba, and W. Hasan, "Heavy Metal Content in Leachate in Banda Aceh Waste Disposal Site (in Bahasa) " in Proceedings of the National Postgraduate Seminar (SNP) Unsyiah, 2017.

[19] Damsir., Suprihatin., M. Romli, M. Yani, and A. Herlambang, "Characteristics of Leachate Anaerobic Fermentation of Solid Waste in Lysimeters and Potential of Its Use as Liquid Fertilizer (in Bahasa)," Teknologi Industri Pertanian, vol. 2, pp. 125-133, 2016.

[20] P. M. I. Torobi, C. N. Manuputty, and J. C. Mangimbulude, "Ammonium (NH4) and Organic Material (COD) reduction on Landfill Leachate through Continuous Anaerobic and Aerobic Cultures-Algae Systems," in National Seminar XII Biology Education of Faculty Education and Science, State University Surakarta, 2015.

[21] A. R. Putri, G. Samudro, and D. S. Handayani, "Penentuan Rasio BOD/COD optimal pada reaktor Aerob, Fakultatif dan Anaerob," 2012.

[22] C. G. I. Partha, "Use of Organic Waste as a Power Plant at the Suwung Landfill in Denpasar (in Bahasa)," Teknologi Elektro, General Soedirman University, vol. 9, 2010.

[23] R. P. Dewi, "Study of the Potential Utilization of Organic Waste at Banyuurip Tegalrejo Landfill as One Energy Source," Mechanical Engineering Department, Tidar University, Magelang2017.

[24] Q. Xue and L. Liu, "Study on optimizing evaluation and recovery efficiency for landfill gas energy collection,"Environmental Progress \& Sustainable Energy", vol. 33, pp. 972-977, 2014.

[25] Kohler, "https://www.clarke-energy.com/landfillgas/," in Landfill Gas. Clarke Energy A Kohler Company vol. 2018, ed, 2017.

[26] C. Banks, "Optimising Anaerobic Digestion," University of Southampton2009. 